\title{
Brooding in a temperate zone land snail: seasonal and regional patterns
}

\author{
Anna Sulikowska-Drozd ${ }^{1,4}$, Tomasz K. Maltz ${ }^{2}$, Heike Kappes ${ }^{3}$ \\ ${ }^{1}$ Department of Invertebrate Zoology and Hydrobiology, University of Łódź, Banacha Str. 12/16, 90-237 Łódz,, \\ Poland \\ ${ }^{2}$ Museum of Natural History, Wrocław University, Sienkiewicza 21, 50-335 Wrocław, Poland \\ ${ }^{3}$ Naturalis Biodiversity Center, P.O. Box 9517, 2300 RA Leiden, The Netherlands \\ ${ }^{4}$ E-mail:sulik@biol.uni.lodz.pl
}

Key words: Clausiliidae, Gastropoda, life cycle, moisture, Mollusca, viviparity

\begin{abstract}
The goal of this study is to assess if the reproductive strategy of a brooding land snail shifts along a climatic gradient. We focused on the following traits: timing and length of the reproductive season, brood size, ontogenetic dynamics of embryos, and reproductive mode (viviparity versus egg-laying). We dissected the central European door snail Alinda biplicata, collected monthly from eight populations covering the oceaniccontinental climatic gradient within the species' distribution range. Forty percent of the 1706 dissected individuals were brooding. The species displayed a spring-summer reproductive activity pattern: intrauterine brooding was recorded between March and September; first embryos of a developmental stage that equals that of live-born neonates appeared in late April. Brooding started approximately when the mean daily temperature of a month exceeds ca. $5^{\circ} \mathrm{C}$, thus the ontogenetic development of embryos is advancing earlier in populations under the influence of mild oceanic climate, and later in the eastern, more continental part of the range, or in submontane localities. A range-wide synchrony in reproduction occurred in May, when average temperatures and precipitation display a high rangewide similarity. The mean number of intrauterine eggs decreased between spring and summer in all populations (April: $10.9 \pm 2.9$; September: $6.4 \pm 2.4$ ), suggesting a gradual release of neonates which are not immediately replaced in uteri by new eggs. Snails from areas with long frosty winters do not invest much in a second reproductive period in late summer. Embryos of advanced embryonic stage were found in the reproductive tract of individuals from each population, thus we refute the hypothesis that $A$. biplicata switches its reproductive strategy towards oviparity under the influence of oceanic climate.
\end{abstract}

\section{Contents}

Introduction

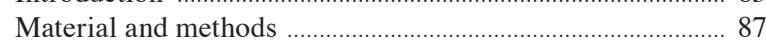

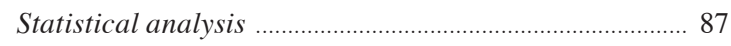

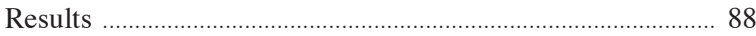

Between-site differences in timing and length of the reproductive period

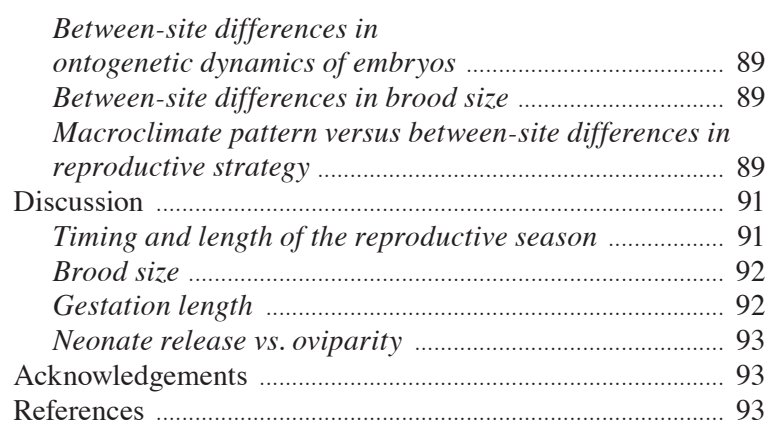

\section{Introduction}

Components of the reproductive investment, such as the number of offspring, their size at birth, and the time parents devote to breeding, are under strong selective pressure from environmental constraints. Several taxa let their offspring develop inside the parental body to protect the developing embryos against harsh external conditions. Adaptations to internal embryo protection (viviparity or ability to retain eggs) are well-known examples of convergence in vertebrates where these adaptations have evolved at least 150 times (Blackburn, 1999a, 2006). Similar strategies were found in other animal groups (Clutton-Brock, 1991; McGhee, 2011), where development of embryos occurs in modified reproductive tracts (oviduct, uterus) or in other specialised brood chambers. For convenience, the term brooding is often applied in invertebrates to describe the variety of viviparous-like or eggretaining reproductive strategies.

Brooding evolved repeatedly in molluscs. While the overwhelming majority of marine species are oviparous and produce free-swimming larvae, viviparity occurs in several freshwater snails and bivalves (Glaubrecht, 
2006). Köhler et al. (2004) hypothesised that an unpredictability of abiotic factors and food supply in freshwater habitats requires a higher parental investment per offspring and triggered the repeated evolution of direct development in large encapsulated eggs which, in turn, can be considered a preadaptation towards viviparity.

Uterine brooding is widespread in land snails (Tompa, 1979a), where it might be advantageous when an individual cannot otherwise provide successful protection against egg desiccation or over-hydration (Owiny, 1974; Baur, 1994; Heller et al., 1997). Brooding improves the reproductive success through increased juvenile survival and production of numerous clutches throughout the year (Carvalho et al., 2009). However, clutches in egg-retainers are smaller than in oviparous gastropods of similar size (Baur, 1994), because the offspring develops in the constrained space of the reproductive tract (Anderson et al., 2007).

Brooding is frequent in the species-rich family Clausiliidae, and egg retaining species are found in at least four genera in Europe (Maltz and SulikowskaDrozd, 2008; Szybiak, 2010; Sulikowska-Drozd et al., 2012). Here, we focus on Alinda biplicata (Montagu, 1803), a common central European clausiliid that is well-suited for studies on environmental constraints on reproduction because of its wide geographical range, high habitat tolerance (Kerney et al., 1983) and probable variation in its reproductive mode (Fechter and Falkner, 1990). The distribution of A. biplicata in Europe ranges from northeastern France to the Vistula river in Poland and to southern Sweden, indicating a limitation by macroclimatic factors rather than by geographical barriers. Isolated populations in southern England and Norway occur in anthropogenic habitats, where the species was apparently introduced (Kerney et al., 1983).

The first record of live-bearing reproduction in $A$. biplicata dates back to Held (1837, in Moquin-Tandon 1855), who referred to the species as Clausilia vivipa$r a$ Held, 1837. Steenberg (1914) reported that the snail retained fertilized eggs in a broadened oviduct and eventually gave birth to juveniles, but Loosjes (1941, after Frömming, 1954) also observed egg-laying. More recently, Fechter and Falkner (1990) reported that $A$. biplicata could lay eggs with well-developed embryos in favourable conditions, which suggests that the intrauterine phase may be shortened in some circumstances and followed by an external development of the eggs. According to Maltz and Sulikowska-Drozd (2012), litters of A. biplicata released under constant laboratory conditions usually consist of 2-3 neonates, but can reach a maximum of 11 neonates per batch. A pair of snails produces 6-39 offspring per year. The authors also observed that juveniles complete shell growth within 20-28 weeks, reach maturity in another 24-36 weeks and live 4-6 years.

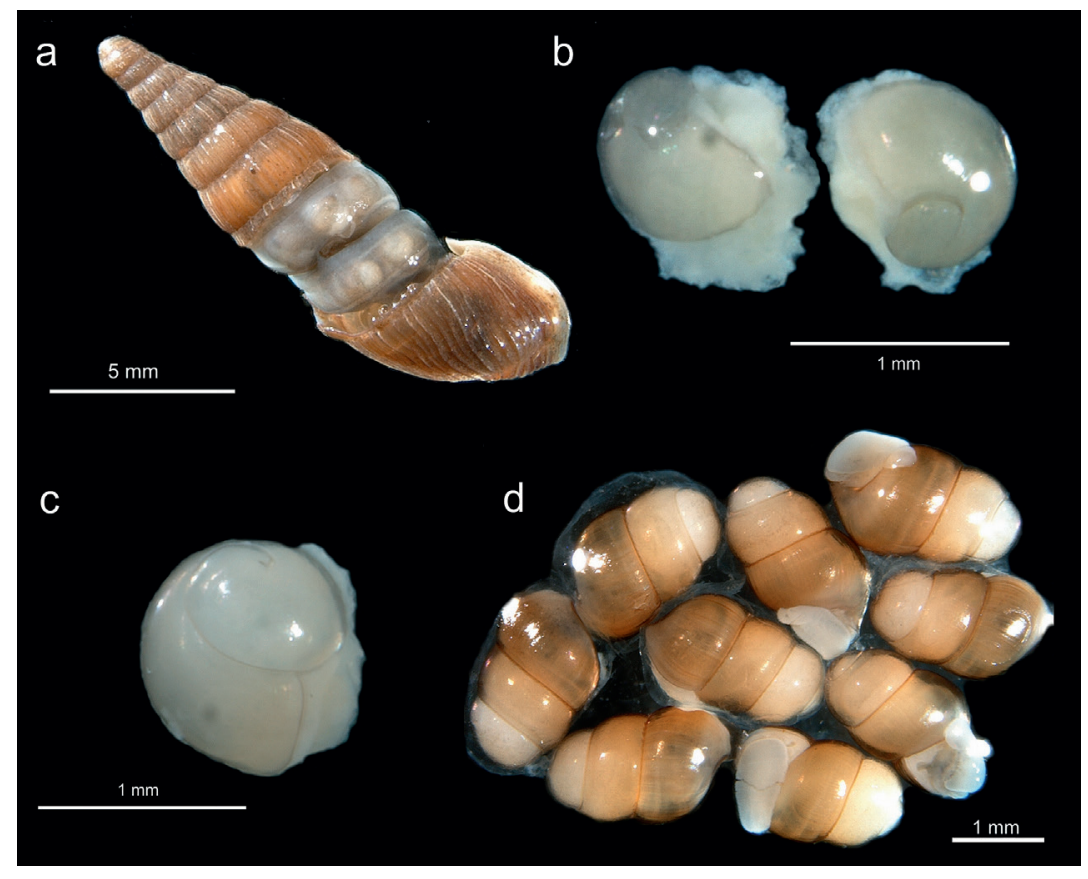

Fig. 1. a) adult specimen of Alinda biplicata with shell partly removed showing uterus with embryos; b-d) embryos from dissected adults stage II, stage III, stage IV. 
The reproduction of A. biplicata was classified as 'ovoviviparous' in reviews on land snail reproductive strategies (Tompa, 1979b; Heller, 2001). According to recent terminology, 'viviparity' should be addressed to live-bearing species which retain embryos to term, or in which hatching precedes or accompanies parturition, followed by a bipartite classification into lecithotrophy or matrotrophy depending on the embryonic nutritional pattern (Blackburn, 1999b). The nutrient transfer between parent and intrauterine embryo is insufficiently studied in land snails and direct evidence for matrotrophy exists only for few taxa, for example Stylodon studeriana Ferrusac, 1821 (Heller, 2001). Since the current knowledge does not allow a final classification of the reproductive strategy of A. biplicata, we used here the term brooding, as it does not discriminate between oviparous egg-retention, lecithotrophic or matrotrophic viviparity.

The aim of this paper is to examine whether along the climatic gradient there is a shift in A. biplicata in (1) timing and length of the reproductive season, (2) brood size, or (3) ontogenetic dynamics of embryos. A further goal is to explore whether there is a shift in reproductive mode from life-bearing to egg-laying strategy within the distribution range of A. biplicata. Because selection is expected to couple reproductive investment to times when resources such as food and water are available, we hypothesized that the timing of breeding season, brood size and embryo development should shift along the west-east axis of the species' range. Under the assumption that the smaller climatic fluctuations in the humid oceanic climate exert fewer constraints on eggs survival, A. biplicata could reduce the time of parental investment per offspring and change its strategy towards oviparity (see Fechter and Falkner, 1990) rather than keeping embryos in the uterus to term. If this assumption is met, intrauterine embryos of a more advanced embryonic stage would be rare in the westernmost populations indicating that contrasting macroclimate might select for major differences in reproductive strategy.

\section{Material and methods}

Alinda biplicata was sampled from eight sites that were located between $7.0^{\circ}$ and $19.4^{\circ} \mathrm{E}$ at similar latitude $\left(50.1-51.8^{\circ} \mathrm{N}\right)$. For details see On-line Supplementary Information (Table S1).

Samples of A. biplicata were taken between March and September over 2 years (2010-2011), but not all sites could be sampled for each month. Each sample included ca. 30 adults per site. Adult status was assigned if individuals displayed a fully developed clausilium and apertural lip. Adult snails were sampled regardless reproductive activity (egg-retaining / not reproducing), as intrauterine eggs are not visible through the shell of the living individual.

Snails were dissected and all brooded eggs/embryos were counted (Fig. 1). The developmental stage of each egg was categorized using the presence of the embryonic shell and the number of its whorls (Kerney et al., 1983) as follows: stage I - egg filled with amorphous substance, no visible shell; stage II - egg with embryo; embryonic shell with < 1 whorl; stage III embryo with shell of 1-1.9 whorls; stage IV - embryo with $>2$ whorls. Stage IV corresponds with the size of live-born neonates (2.1-2.9 whorls) observed in laboratory cultures (Maltz and Sulikowska-Drozd, 2012).

The differences in macroclimatic pattern across sampling sites were expressed as average monthly air temperature and precipitation, downloaded with ArcGIS 9 (ArcMap ver. 9.3) from the 'WorldClim' database at 1-km spatial resolution (Hijmans et al., 2005). These data were presented also as the change $(\Delta)$ between average temperatures or average precipitation in subsequent months (Fig. 2ab). The yearly changes in temperature and precipitation throughout the distribution of the species in Central Europe are presented in Table S1.

\section{Statistical analysis}

Differences in the presence/absence of intrauterine eggs between months and sampling sites were analyzed with chi $^{2}$ tests. Seasonal differences in the number of retained eggs (all eggs and eggs of different developmental stages separately) were analysed by means of ANOVA, using the number of eggs as dependent variable and the months as groups, followed by a Tukey post-hoc test. The regional variance in brood size were analysed using the number of eggs as dependent variable and the localities as grouping factor.

We used multiple logistic regressions to evaluate the relationship between average monthly temperature and precipitation and the presence of intrauterine eggs in A. biplicata. Also, two seasons were included as a categorical variable in the analysis: spring (MarchJune) and summer (July-September). Regressions were computed with stepwise backward selection of variables (probability threshold of F-to-remove $=0.10$ ). Univariate linear regressions were computed to check 
a
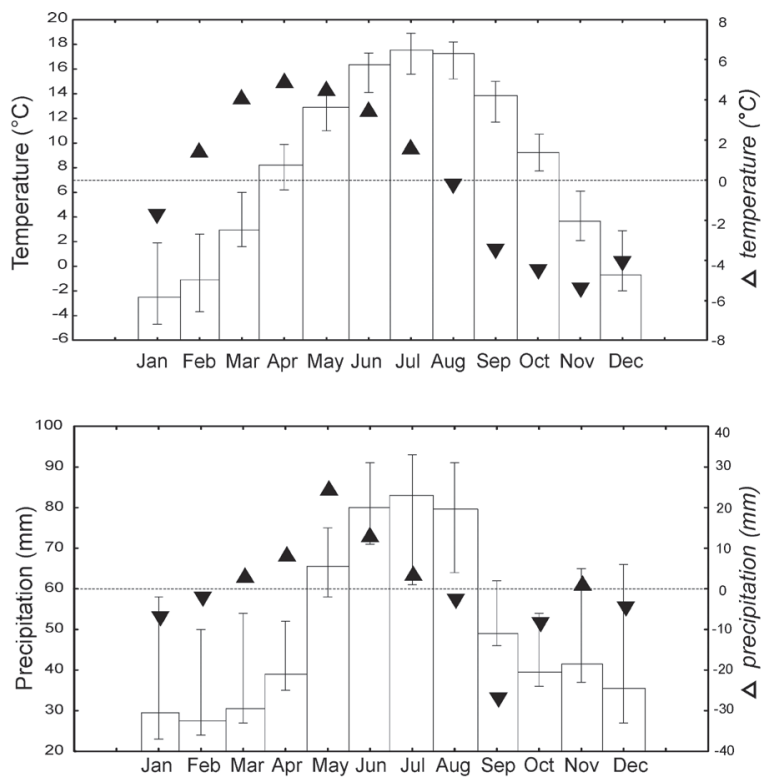

$I_{\text {Min-Max }}$

Comparison to the former month: $\mathbf{\Delta}$ Increase $\boldsymbol{\nabla}$ Decrease

Fig. 2. Monthly changes across eight localities in: (a) average temperature, (b) precipitation, (c) percentage of brooding Alinda biplicata, (d) percentage of developmental stages of intrauterine embryos, (e) and number of uterine eggs per brooding individual.

the influence of climatic variables on brood size. Statistics were calculated using the software packages SPSS (ver. 11.0) and Statistica (ver.10).

\section{Results}

In total, we studied 1706 individuals of Alinda biplicata, 683 of which $(40.0 \%)$ were brooding. The snails brooded a total of 6,420 eggs, that is, the average gravid individual carried $9.4 \pm 2.8$ intrauterine eggs (mean $\pm \mathrm{sd})$. Egg-retention was recorded from late March till late September, however, the frequency of brooding individuals differed in successive months (likelihood ratio $\Lambda=420.3$, df $=6$; $p<0.001$ ) (Fig. 2c). The maximum proportion of reproductively active snails $(70 \%)$ occurred May to June.

In April, the majority of brooded eggs (90.4\%) were at the initial stage of development (stage I). The pro-
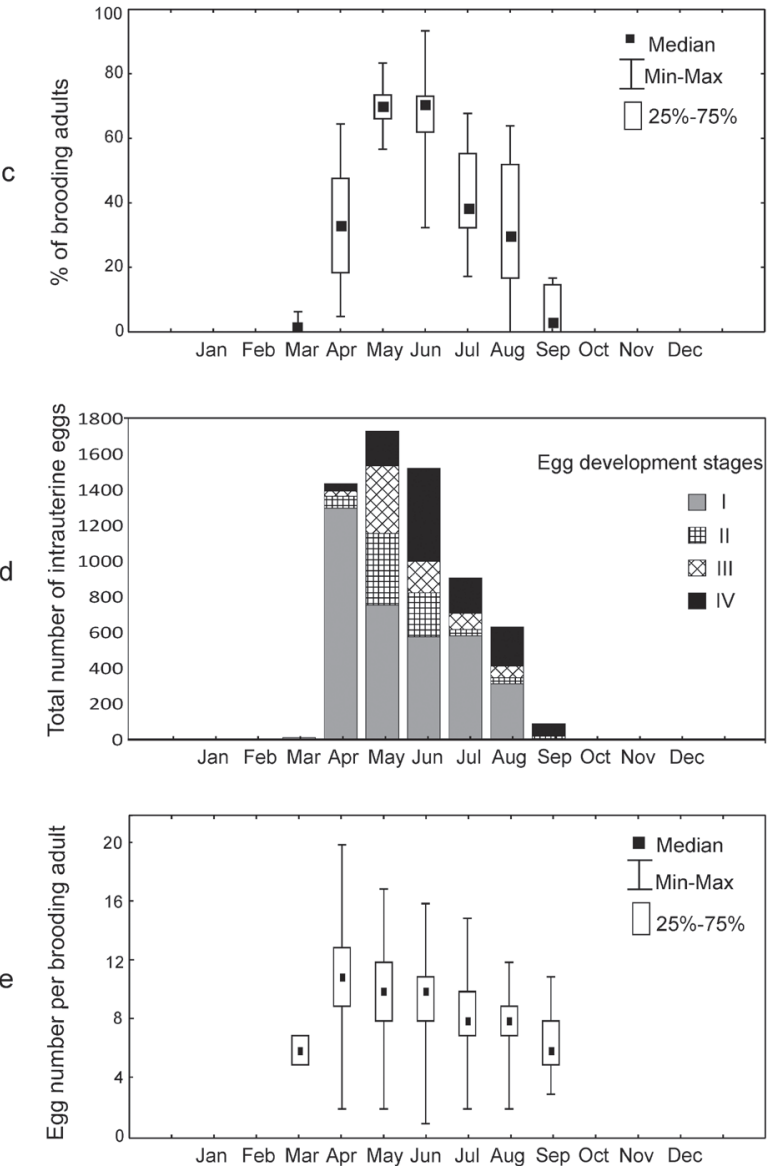

portion of developmental stages shifted between early and late spring (April - June) towards a dominance of more advanced embryos (Fig. 2d). In July, eggs stage I predominated again $(64.2 \%)$, indicating the beginning of a second reproductive period. The number of retained eggs per brooding individual changed during the year (ANOVA: $\left.\mathrm{F}_{(5,672)}=25.2 ; \mathrm{p}<0.0001\right)$. The highest number of eggs was brooded in April (mean $\pm \mathrm{sd}=$ $10.9 \pm 2.9$ ), then the number of retained eggs constantly decreased to $6.4 \pm 2.4$ in September (Fig. 2e).

Monthly differences in brood size were also significant when the analysis was restricted to snails that brooded only eggs of stage I (ANOVA: $\mathrm{F}_{(4,336)}=13.7$; $\mathrm{p}$ $<0.0001)$. Large broods containing only stage I eggs were found in April (11.0 \pm 2.9 eggs). In May-August, broods of such eggs were smaller (from $8.2 \pm 1.8$ to 9.5 \pm 2.4 ) and monthly differences in brood size were not significant (ANOVA: $\left.\mathrm{F}_{(3,220)}=2.5, \mathrm{p}=0.058\right)$. Adults retaining only stage I eggs did not occur in September. 
Between-site differences in timing and length of the reproductive period

In the westernmost site (Cologne) brooding individuals appeared in March (6.3\%), while in other localities, sampled in the same time (Langenselbold, Wrocław and Łódź), snails were not reproductively active (Fig. 3). Between April and July, uterine egg retention occurred in all populations along the longitudinal gradient (Figs 3-4). In the easternmost site (Łódź), however, brooding individuals appeared in low numbers in April 2010 (9.4\%) and were not found in April 2011. Populations did not differ in the proportion of brooding and non-brooding individuals in May when 56 $83 \%$ of individuals were gravid in all regions (likelihood ratio test; $p>0.05$ ). For June, July, August and September, the proportion of brooding and non-brooding individuals differed between sampled localities (likelihood ratio test; $p<0.001$ ). In June, ca. $70 \%$ of the snails were gravid. Extreme values originated from Wrocław (93\%) and Łódź (32\%) (Fig. 3). In July, 30$50 \%$ of the snails retained eggs in most populations, with the exceptions of Langenselbold and Wrocław where more than $60 \%$ of the adults were brooding and Cologne where the percentage of brooders was low (17\%). In August, reproduction ceased in some of the eastern populations: no gravid snails were found in Łódź, and the proportion of gravid individuals was low $(<20 \%)$ in Wrocław and Książ. In September, egg retaining individuals were absent or very rare in most sampled populations except for those from Cologne and Wrocław $(>15 \%)$.

\section{Between-site differences in ontogenetic dynamics of embryos}

The proportion of developmental stages of the brooded eggs changes with time, and regional differences in development rate were observed (Figs 3-4). In April 2010, snails from eastern localities (sites 3 - 8) brooded only eggs without shelled embryos (stage I), whereas the stage I eggs were already accompanied by a low proportion of eggs of stage II and III in snails from the western localities (sites 1 - 2). In 2010, well developed embryos (stage IV) were observed from May (loc. 1, 2, $3,6,8$ ) or from June (loc. 4, 5, 7). In March 2011, only stage I eggs were recorded (loc. 1). In April 2011, a few stage IV embryos were found in individuals from localities 1 and 3, suggesting a enhanced egg development probably as a result from a warmer (micro)climate in these sites. In Langenselbold, we found high numbers of stage I eggs in July and August 2011, that is, a high reproductive activity during summer.

\section{Between-site differences in brood size}

If taking the sampling period as a whole, mean brood size varied among populations (ANOVA: $\mathrm{F}_{(7,672)}=9.5$, $\mathrm{p}<0.0001)$ and ranged from $7.3 \pm 2.5$ eggs in Łódź to $10.5 \pm 3.1$ in Langenselbold.

A gradual decrease of the brood size occurred in all populations between spring and summer. Mean numbers of eggs per brooding individual were highest in April (Cologne - mean 10.3, range 8 - 13; Wrocław mean 12.2 eggs, range 8 - 17; Stronie - mean 10.1 eggs, range 9 - 13, Henryków - mean 12.4 eggs, range 7 - 16) or May (Langenselbold - mean 12.3 eggs, range 8 - 16; Żelazno - mean 10.3 eggs, range 5 - 15; Łódź - mean 8.7 , range 4 - 12). Only in Książ, the mean number of brooded eggs was highest in June (mean 10.9 eggs, range 7 -17). A maximum of 20 intrauterine eggs was found in Langenselbold in April 2010. In summer, the mean number of eggs decreased and large broods were absent.

Macroclimate pattern versus between-site differences in reproductive strategy

Multiple logistic regressions (Table 1) indicate that $70.9 \%$ of variation in the presence/absence of eggs in the uterus of A. biplicata may be explained by mean monthly temperature and precipitation in the locality and the time of sampling (spring months/summer months). Occurrence of intrauterine eggs is enhanced in months with higher temperature and precipitation, yet at similar temperatures reproductive activity is higher in spring (March-June) than in summer/autumn which may indicate the photoperiodic response for increasing day length.

Differences in macroclimate between the sites are greatest in winter, with monthly average January

Table 1. Results of logistic regression of sampling season (spring / summer) and average temperature and precipitation of sampling month on the presence of brooding individuals of Alinda biplicata at eight localities.

\begin{tabular}{lllll} 
& B & S.E. & df & $\mathrm{p}$ \\
\hline Precipitation & 0.017 & 0.005 & 1 & 0.000 \\
Temperature & 0.199 & 0.024 & 1 & 0.000 \\
Season & 2.222 & 0.150 & 1 & 0.000 \\
Constant & -5.431 & 0.329 & 1 & 0.000 \\
\hline
\end{tabular}



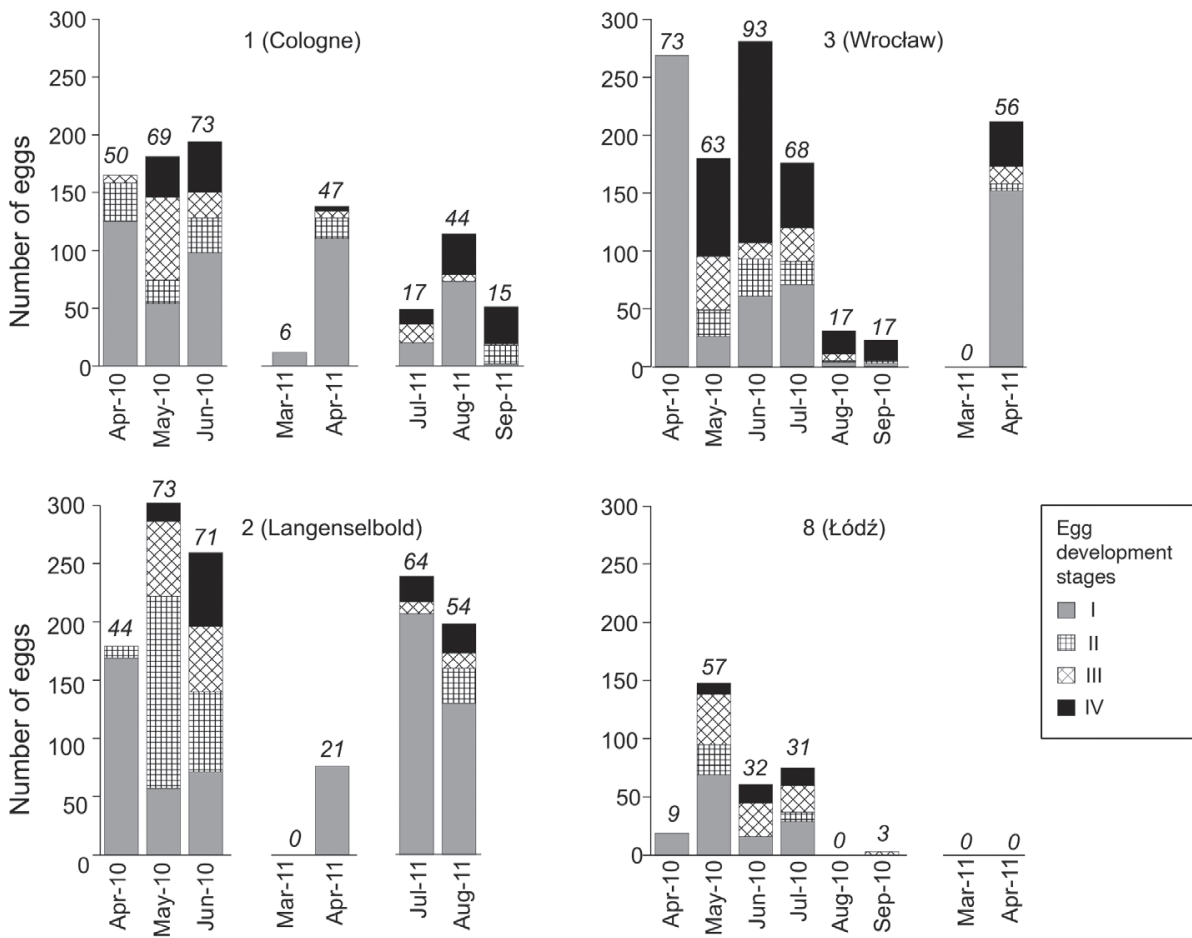

Fig. 3. Total number of intrauterine eggs in different developmental stages in populations of Alinda biplicata sampled in 2010 and 2011. Numbers above bars indicate the percentage of brooding snails in a sample.
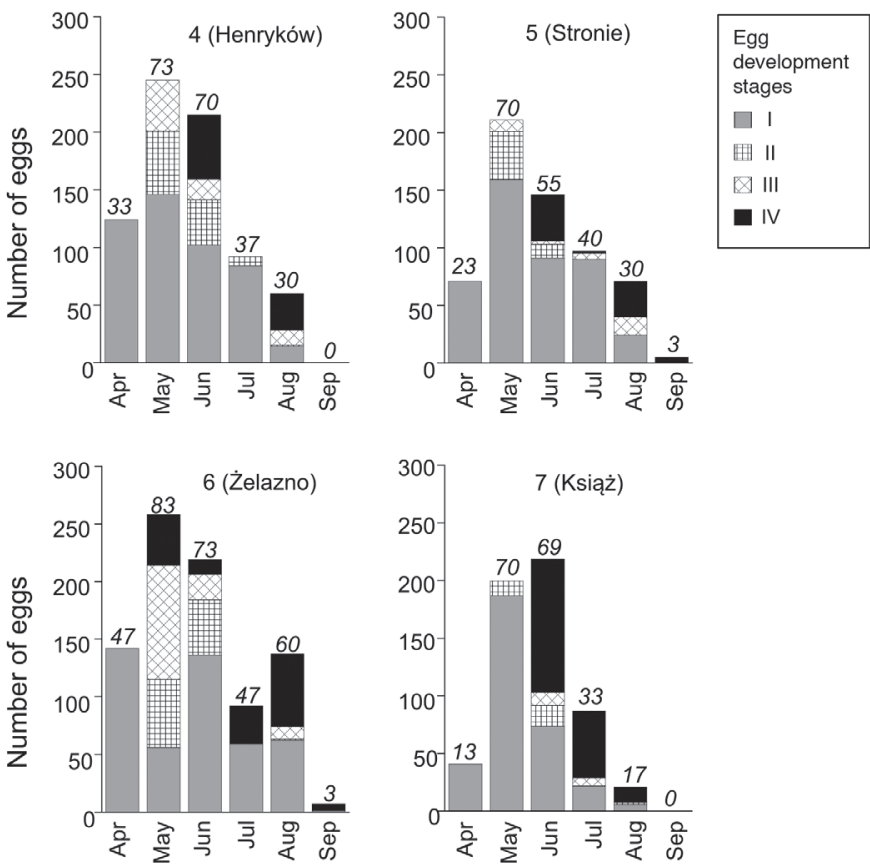

Fig. 4. Total number of intrauterine eggs in different developmental stages in Alinda biplicata populations sampled in 2010. Numbers above bars indicate the percentage of brooding snails in a sample.

temperatures down to $-4.7^{\circ} \mathrm{C}$ in the easternmost site (Łódź), but $1.9^{\circ} \mathrm{C}$ in the westernmost site (Cologne) (range: almost $7^{\circ} \mathrm{C}$ ). Average March temperatures range from $1.6^{\circ} \mathrm{C}$ in the East to $6.0^{\circ} \mathrm{C}$ in the West, while average April temperatures range from $6.2^{\circ} \mathrm{C}$ to $9.9^{\circ} \mathrm{C}$, respectively.

The reproduction of A. biplicata started in March in Cologne and in April in the other sites. In April, 90.4\% 
of the brooded eggs were at stage I of development and more developed embryos (stages II \& III) were recorded only in localities (sites 1-3) with the highest average temperatures. It seemed that the minimal average daily temperature required for the onset of the species reproduction was about $5-6^{\circ} \mathrm{C}$.

May is the month with a low among-site variation in average temperature (coefficient of variation $=8.2$; range: $11.0^{\circ} \mathrm{C}-13.9^{\circ} \mathrm{C}$ ) and the lowest among-site variation in precipitation $(\mathrm{cv}=9.3)$. May also is the last month in a row with a monthly average temperature increase $>4^{\circ} \mathrm{C}$ (Fig. 2a), and nights at or below the freezing point are getting unlikely. Another potential factor for snail reproduction is the high increase in mean monthly precipitation $(66 \pm 6 \mathrm{~mm})$ when compared to April (41 $\pm 6 \mathrm{~mm}$ ) (Fig. 2b). The similar brooding frequencies in A. biplicata from different populations in May (see above) mirrors a temporal range-wide homogeneity of macroclimate.

In July and August, average temperatures range from $15.2^{\circ} \mathrm{C}$ to $18.9^{\circ} \mathrm{C}$. The highest monthly averages were recorded at the western and eastern margins of the species range (localities 1,2 and 8). Despite the similar average temperatures of May and September (Fig. 2a), our data indicated that the latter month is associated with a cease in A. biplicata reproduction. September is the first month in a row when average monthly temperatures drop for $>3^{\circ} \mathrm{C}$ per month (av. temp. $11.7^{\circ} \mathrm{C}-15.0^{\circ} \mathrm{C}$ ). September also is significantly drier when compared to July and August (Fig. 2b, Table S1). Reproduction of A. biplicata is less intense at localities 3-8 during late summer and finally stops in late September. Based on the data from March, the population from Cologne also seems to suppress the reproduction at some time in autumn. In early October, frost nights can occur in the eastern part of the sampling range, and from mid-October on, frost can occur in its western part.

As the seasonal changes in the number of retained eggs were significant (see above), we scrutinized the relationships between brood size and the climatic characteristics of the localities for each month separately.

We found a pattern in occurrence of eggs stage $I$ in late spring (June). The mean number of eggs at stage I negatively correlated with the average temperature of summer months (June-August) (Pearson $r=-0.739, p$ $=0.036)$ and positively correlated with precipitation in June ( $r=0.878, p=0.004)$, meaning that the number of such eggs in late spring was higher at localities with a cooler and more humid summer (sites 4-6).
In addition, brood size in July was positively correlated with 1) the winter temperatures (average for December-February) (Pearson $r=0.749, \mathrm{p}=0.032), 2$ ) average annual temperature $(\mathrm{r}=0.714, \mathrm{p}=0.047), 3)$ January precipitation $(\mathrm{r}=0.769, \mathrm{p}=0.026)$, 4) April precipitation $(r=0.775 \mathrm{p}=0.024), 5)$ October precipitation $(r=0.824, p=0.012)$. These findings suggest that the number of eggs produced during summer was higher at localities with mild winters and sufficient precipitation. Only western populations of A. biplicata experience average temperature of winter months above $0^{\circ} \mathrm{C}$ and monthly precipitation above $40 \mathrm{~mm}$. Eastern populations do not invest much in the second reproduction period in summer.

\section{Discussion}

\section{Timing and length of the reproductive season}

In seasonal climates, the appropriate timing of reproductive activities such as egg-laying and hatching strongly determines juvenile survival. This even holds true for seasonal tropical climates where low temperatures are not limiting, and hatching is linked to the rainy season. For example, Limicolaria martensiana E.A. Smith 1880 in Uganda retains eggs and young in utero during aestivation and deposits them when rain returns (Owiny, 1974). In this case, brooding allows an early start of the reproduction by incubating developing embryos during unfavourable conditions and by releasing as soon as the weather is suitable. In the Mediterranean region, clausiliids mate and produce offspring in winter in response to the cool rains and they cease reproductive activity and aestivate during the hot, dry spring and summer (Heller and Dolev, 1994; Giokas and Mylonas, 2002).

In Central Europe, winter temperatures drop below the freezing point for several months which limits the vegetation growing season. Most land snails of Central Europe reproduce soon after hibernation or from spring till autumn (e.g., Terhivou, 1978; Pokryszko, 1990; Kuźnik-Kowalska, 1999). Eggs of some slugs and semislugs laid in late autumn hatch in the following spring (Umiński, 1979; Wiktor, 1989). According to Mamatkulov (2007), egg laying clausiliids reproduce between May and August. Brooding clausiliids such as Ruthenica filograna (Rossmässler, 1836) and Balea (Pseudalinda) fallax (Rossmässler, 1836) retain developing embryos in uteri from March to October and from May to August, respectively (Szybiak, 2010; 
Sulikowska-Drozd, et al., 2012). Apparently, clausiliids from the temperate zone do not retain eggs during hibernation. This strategy is different from other egg retaining land snails of the same region, for example, the pupillid Pupilla muscorum (Linnaeus, 1758) usually overwinters while gravid (Frömming, 1954; Pokryszko, 2001).

Recently, Maltz and Sulikowska-Drozd (2010) analysed the circannual gonad activity in the clausiliids Vestia gulo (E.A. Bielz, 1859) and V. turgida (Rossmässler, 1836) which also retain eggs in uteri during spring and summer (Sulikowska-Drozd, 2009). It was found that the onset of embryo development is determined by the available pool of matured oocytes. Production of oocytes starts in the end of summer and their maturation occurs in March-May the following year. Vitellogenic oocytes are absent in the gonads in late summer, autumn and winter.

Our results indicate that A. biplicata displays a spring-summer reproductive activity pattern. The low percentage of brooding individuals in early spring and autumn along with the dominance of stage I eggs in March and April suggests that, as in other clausiliids of the region, egg-retention ceases during winter and starts again in spring. In spring, the beginning of uterine brooding in A. biplicata coincides with the onset of the vegetation growing season (average daily temperature $>5^{\circ} \mathrm{C}$ ) which is earlier in the western than in the eastern part of the species distribution range. Consequently, there is a spatio-temporal gradient in the developmental stage of the embryos across the species range in early spring. Also, the mid-spring synchrony of reproduction (high percentage of gravid snails in all populations in May) suggests selection pressures from temperature and moisture. In areas with higher winter temperatures, A. biplicata invests more in a second reproductive period in late summer. Because the reproductive activity of A. biplicata was closely linked to macroclimate, we suppose that the species geographic distribution also is strongly affected by suitable climatic conditions.

The remaining variation might be explained by density-dependent factors within the studied populations. Intra- and interspecific competition can result in a decreased reproduction rate in overcrowded populations, as evidenced by Baur (1990) for clausiliid B.perversa (Linnaeus, 1758). We did not estimate the density of the sampled populations of A. biplicata in this study, which may vary during a season as a result of juvenile recruitment, but also abiotic factors affecting survival. Winter floods seem to result in a higher re- productive output. A high number of neonates occurred in the Langenselbold population probably because the juveniles of the proceeding year are more susceptible to winter inundation and/or drift than were adults (Kappes, pers. obs.). The reproductive effort of this population is mirrored in the high proportion of reproducing individuals and high fecundity (this study). Similarly, pre-sampling flooding happened at Wrocław where the population also had a high proportion of gravid individuals that produced high numbers of eggs.

\section{Brood size}

According to Frömming (1954), Alinda biplicata gives birth to 1-11 neonates at a time. When kept in cultures, it produces a series of litters at short intervals with an average 2.8 juveniles per litter (Maltz and SulikowskaDrozd, 2012). In natural populations of A. biplicata, we observed a decrease in the number of brooded eggs during the season. This observation suggests that juveniles are born gradually (in small litters) and released offspring is not immediately replaced in uteri by new eggs. This pattern is consistent in all studied populations of A. biplicata. Delivering small litters with high frequency was found also in other brooding land snails (Carvalho et al., 2009). It can be understood as a riskspreading strategy, but in some smaller species (e.g. Balea perversa, Ruthenica filograna) it may result from parental size limitation.

\section{Gestation length}

Our survey was not designed to measure the duration of the intrauterine development of a particular embryo. Laboratory observation on oviparous clausiliids suggests that eggs hatch about two weeks after deposition and that the incubation period only in rare cases exceeds three weeks at room temperature (Heller and Dolev, 1994; Maltz and Sulikowska-Drozd, 2008; Maltz and Pokryszko, 2009). We assume that the time needed for embryonic development is similar in brooding species, but that the brooding period may lengthen if environmental conditions are not suitable for neonates. Forced egg retention, that is, beyond the normal time of parturition, was never studied experimentally in brooding land snails, yet, Baur (1990) states that the size of newborn Balea perversa was related to the duration of intrauterine development and not to parent size.

This finding suggests some adaptive flexibility in clausiliid brooding towards short and unpredictable 
spells of adverse weather during the vegetation growing season: Embryos of A. biplicata are delivered as soon as they reach a certain developmental stage, or they can be retained until outside conditions are optimal. The latter option, probably evolutionarily advantageous, might explain our occasional records of exceptionally large embryos ( $>3.0$ whorls) in uteri of $A$. biplicata.

\section{Neonate release vs. oviparity}

We assume that the releasing of neonates by A. biplicata is preceded by the presence of well-developed embryos in uteri. If so, regional climatic differences can cause a temporal shift in the emergence of the new generation. The significant delay in embryonic development in submontane populations (Stronie, Książ) is an indication of adjusting reproduction to temperatures.

The period when stage IV embryos were brooded in populations in Langenselbold and Łódź coincides with first spring observations of neonates crawling in leaf litter at these localities on 12 May and 20 May 2010, respectively (Kappes and Sulikowska-Drozd, pers. obs.). Our findings are also in congruence with results of the field study on population dynamics of A. biplicata undertaken by Kuźnik-Kowalska (1998) at the foothills of the Sudetes (SW Poland). According to the author, neonates of A. biplicata appear between June and August.

Our study found that well-developed embryos (stage IV, even 2.8-3.3 whorls) were kept in the reproductive tract by individuals from each population, indicating a stability of the major reproductive strategy throughout the distribution range irrespective of the macroclimatic regime. Thus, we refute the hypothesis that $A$. biplicata switches its reproductive strategy towards oviparity under the influence of an oceanic climate. Incidental cases of A. biplicata laying eggs, as reported by Frömming (1954) and Fechter and Falkner (1990), might be triggered by some short term environmental cue influencing parturition.

To conclude, we found that reproduction of A. biplicata occurs between March and September, paralleling the vegetation growing season. The dynamic of intrauterine embryo development follows spatio-temporal changes of both temperature and moisture. Populations in areas with higher winter temperatures have a head start in spring reproduction and invest more in a second reproductive period in late summer and early fall, but our study does not indicate a general shift in the reproductive mode towards oviparity under oceanic climate conditions in the western part of the range. Because of their strong ties to reproduction, climatic variables may be the dominant factor for the geographical distribution of A. biplicata in Europe.

\section{Acknowledgements}

ASD and TKM received National Science Center grant (NN303 796740) for studying reproduction modes in clausiliids. HK received financial support from the Netherlands Organization for Scientific Research (NWO - ALW 821.01.002) during manuscript preparation. We thank Zbigniew Wojciechowski for discussion on data analysis, and Virginia Hayssen, Daniel G. Blackburn, Beata M. Pokryszko and anonymous reviewers for their helpful comments on a former version of the manuscript.

\section{References}

Anderson TK, Weaver KF, Guralnick RP. 2007. Variation in adult shell morphology and life-history traits in the land snail Oreohelix cooperi in relation to biotic and abiotic factors. Journal of Molluscan Studies 73: 129-137.

Baur A. 1990. Intra- and interspecific influences on age at first reproduction and fecundity in the land snail Balea perversa. Oikos 57: 333-337.

Baur B. 1994. Parental care in terrestrial gastropods. Experientia 50: 5-14.

Blackburn DG. 1999a. Are viviparity and egg-guarding evolutionarily labile in sqamates? Herpetologica 50: 556-573.

Blackburn DG. 1999b. Viviparity and oviparity: evolution and reproductive strategies. Pp. 994-1003 in: Knobil TE, Neill JD, eds, Encyclopedia of Reproduction. New York: Academic Press.

Blackburn DG. 2006. Squamate reptiles as model organisms for the evolution of viviparity. Herpetological Monographs 20: 131-146.

Carvalho CM, Silva LC, Mendonca CLF, Bessa ECA, D’Ávila S. 2009. Life history strategy of Leptinaria unilamellata (d'Orbigny, 1835) (Mollusca, Pulmonata, Subulinidae). Invertebrate Reproduction and Development 53: 211-222.

Clutton-Brock TH. 1991. The Evolution of Parental Care. Princeton: Princeton University Press.

Fechter R, Falkner G. 1990. Weichtiere. München: Mosaik Verlag.

Frömming E. 1954. Biologie der mitteleuropäischen Landgastropoden. Berlin: Duncker und Humblot.

Giokas S, Mylonas M. 2002. Spatial distribution, density and life history in four Albinaria species (Gastropoda, Pulmonata, Clausiliidae). Malacologia 44: 33-46.

Glaubrecht M. 2006. Independent evolution of reproductive modes in viviparous freshwater Cerithioidea (Gastropoda, Sorbeoconcha) - a brief review. Basteria, suppl. 3: 23-28.

Heller J. 2001. Life History Strategies. Pp. 413-445 in: Barker GM, ed., The Biology of Terrestrial Molluscs. Wallingford: CABI Publishing. 
Heller J, Dolev A. 1994. Biology and population dynamics of a crevice-dwelling landsnail, Cristataria genezarethana (Clausiliidae). Journal of Molluscan Studies 60: 33-46.

Heller J, Sivan N, Hodgson AN. 1997. Reproductive biology and population dynamics of an ovoviviparous land snail Lauria cylindracea (Pupillidae). Journal of Zoology 243: 263-280.

Hijmans RJ, Cameron SE, Parra JL, Jones PG, Jarvis A. 2005. Very high resolution interpolated climate surfaces for global land areas. International Journal of Climatology 25: 19651978.

Kerney MP, Cameron RAD, Jungbluth JH. 1983. Die Landschnecken Nord- und Mitteleuropas. Hamburg und Berlin: Verlag Paul Parey.

Köhler F, Rintelen Tv, Meyer A, Glaubrecht M. 2004. Multiple origin of viviparity in Southeast Asian gastropods (Cerithioidea: Pachychilidae) and its evolutionary implications. Evolution 58: 2215-2226.

Kuźnik-Kowalska E. 1998. Life cycle and population dynamics of Alinda biplicata (Montagu, 1803) (Gastropoda: Pulmonata: Clausiliidae). Folia malacologica 6: 33-37.

Kuźnik-Kowalska E. 1999. Life cycle and population dynamics of Discus rotundatus (O.F. Müller, 1774) (Gastropoda: Pulmonata: Endodontidae). Folia malacologica 7: 5-17.

Mamatkulov AL. 2007. Breeding biology of some East European Clausiliidae species (Mollusca, Pulmonata). Zoologichesky Zhurnal 86: 403-414.

Maltz TK, Pokryszko BM. 2009. Macrogastra badia (C. Pfeiffer, 1828) (Gastropoda: Pulmonata: Clausiliidae) in Zieleniec (Bystrzyckie Mts, Central Sudetes) - ecology, conservation status and life history - preliminary data. Folia malacologica 17: 53-62.

Maltz TK, Sulikowska-Drozd A. 2008. Life cycles of clausiliids of Poland - knowns and unknowns. Annales Zoologici 58: 857-880.

Maltz TK, Sulikowska-Drozd A. 2010. Circannual gonad activity in two species of the genus Vestia P. Hesse (Gastropoda: Pulmonata: Clausiliidae). Annales Zoologici 60: 469-480.

Maltz TK, Sulikowska-Drozd A. 2012. Life history of Alinda biplicata (Montagu, 1803) (Gastropoda: Pulmonata: Clausiliidae) based on five-year laboratory observations. Annales Zoologici 64: 789-807.

McGhee GR. 2011. Convergent evolution: limited forms most beautiful. Cambridge: Massachusetts Institute of Technology Press.

Moquin-Tandon A. 1855. Histoire naturelle des mollusques terrestres et fluviatiles de la France contenant des etudes générales sur leur anatomie et leur physiologie et la descrip- tion particulière des genres, des espèces et des variétés. Tome second. Paris: JB. Baillière.

Owiny AM. 1974. Some aspects of the breeding biology of the equatorial land snail Limicolaria martensiana (Achatinidae: Pulmonata). Journal of Zoology 172: 191-206.

Pokryszko BM, 1990. Life history and population dynamics of Vertigo pusilla O.F. Müller, 1774 (Gastropoda: Pulmonata: Vertiginidae), with some notes on shell and genital variability. Annales Zoologici 43: 407-432.

Pokryszko BM. 2001. Observations on seasonal dynamics of age structure and reproduction of Pupilla muscorum L. (Gastropoda: Pulmonata: Pupillidae). Folia malacologica 9: 45-50.

Steenberg CM. 1914. Anatomie des Clausilies danoises. I. Les organes génitaux. Mindeskr. Japetus Steenstrup 29: 1-44.

Sulikowska-Drozd A. 2009. Egg retention and ovoviviparity in clausiliids of the genus Vestia P. Hesse (Gastropoda: Clausiliidae). Journal of Molluscan Studies 75: 351-359.

Sulikowska-Drozd A, Maltz TK, Stachyra P. 2012. Egg retention in the clausiliid Balea (Pseudalinda) fallax (Rossmässler, 1836) from Roztocze (S.E. Poland). Folia malacologica 20: 35-38.

Szybiak K. 2010. Ruthenica filograna (Rossmässler, 1836) (Gastropoda: Pulmonata: Clausiliidae). Structure, variation, life cycle, ecology and distribution. Poznań: Wydawnictwo Kontekst.

Terhivou J. 1978. Growth, reproduction and hibernation of Arianta arbustorum (L.) (Gastropoda, Helicidae) in southern Finland. Annales Zoologici Fennici 15: 8-16.

Tompa AS. 1979a. Studies on the reproductive biology of gastropods: Part 1. The systematic distribution of egg retention in the subclass Pulmonata (Gastropoda). Journal of the Malacological Society of Australia 4: 113-120.

Tompa AS. 1979b. Oviparity, egg retention and ovoviviparity in Pulmonates. Journal of Molluscan Studies 45: 155-160.

Umiński T. 1979. Life History in Eucobresia nivalis (Dumont et Morillet) with Notes on two Other Vitrinidae (Mollusca, Gastropoda). Bull. Acad. Pol. Scient. Cl. II, 27: 205-210.

Wiktor A. 1989. Limacoidea et Zonitoidea nuda - Ślimaki pomrowikokształtne (Gastropoda: Stylommatophora). Fauna Polski 12, Warszawa: PWN.

Received: 3 January 2013

Revised and accepted: 25 April 2013

Published online: 24 May 2013

Editor: J.W. Arntzen

\section{On-line Supplementary Information (SI)}

S1. Sampling localities with climatic data based on Hijmans et al. (2005). 


\begin{tabular}{|c|c|c|c|c|c|c|c|c|}
\hline \multirow{12}{*}{ 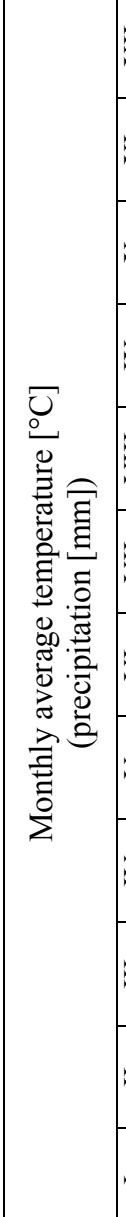 } & $\bar{x} \bar{i} \bar{c}$ & तi & ị & 위응 & 뭉 & 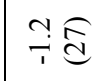 & $9 \stackrel{0}{\circ}$ & 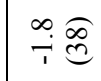 \\
\hline & $\bar{x} \overline{0} \overline{\hat{\theta}}$ & 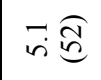 & केष्ठ & वृत् & 社金 & 강 & îf & 然序 \\
\hline & 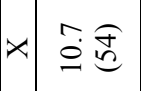 & 䤅 & 芯危 & $\vec{\sigma}: \widehat{\infty}$ & 尺余 & $\begin{array}{l}\infty \\
\infty \\
\infty\end{array}$ & $\infty$ 疋 & ma \\
\hline & $\exists \cong \widehat{\widehat{C}}$ & 守垔 & 过守 & 的存 & 焉 & 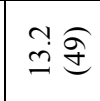 & $\stackrel{\infty}{i} \hat{i}$ & 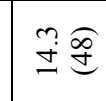 \\
\hline & 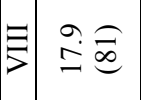 & 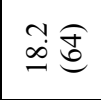 & $\stackrel{ \pm}{\Xi} \hat{g}$ & $\vec{\Xi} \stackrel{\infty}{=}$ & ṽa & உब & 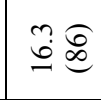 & $\stackrel{1}{\infty}$ \\
\hline & 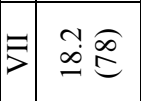 & $\stackrel{\dot{\alpha}}{\dot{\alpha}} \hat{\sigma}$ & $\stackrel{\tilde{\infty}}{\tilde{\Xi}}$ & $\stackrel{+}{\stackrel{f}{\Xi} .}$ & 萨 & 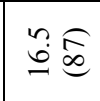 & 宛 & $\begin{array}{l}\infty \\
\stackrel{\infty}{\infty}-\infty\end{array}$ \\
\hline & 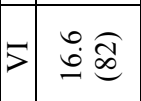 & ?בE & 旾 $\hat{\theta}$ & 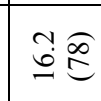 & $\overrightarrow{ \pm} \widehat{\partial}$ & 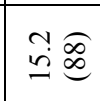 & 雍唐 & $\hat{\dot{\theta}} \hat{\theta}$ \\
\hline & $>\stackrel{\circ}{\mathrm{g}} \bar{\sigma}$ & बेंब्र & 명 & 焉 & $\stackrel{\circ}{=} \hat{\varepsilon}$ & $\stackrel{ }{i} \hat{I}$ & $\stackrel{+}{=} \widehat{S}$ & 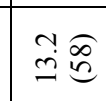 \\
\hline & $\geq$ ¿ & 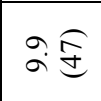 & 象危 & कळ & ชุ. & 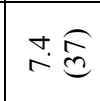 & 浖 & क人 \\
\hline & $\equiv$ 适 & 的整 & $m \underset{d}{\infty}$ & শુశ్త & 우 & $\stackrel{i}{i} \underset{d}{\stackrel{\infty}{d}}$ & તંત્ల్ర & i命 \\
\hline & $=\stackrel{\text { i }}{i}$ 兑 & 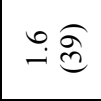 & 옹 & 官过 & 공 & 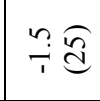 & 赵 & $\ddot{i g}$ \\
\hline & $-a \stackrel{\overrightarrow{0}}{n}$ & 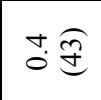 & તંઢ્d & フં & $\stackrel{\sim}{)} \widehat{d}$ & 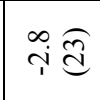 & 诗 & 守㞋 \\
\hline 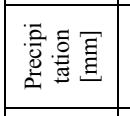 & $\stackrel{\infty}{\circ}$ & 菏 & $\tilde{n}$ & in & 茴 & $\stackrel{\infty}{\circ}$ & हे & $n$ \\
\hline 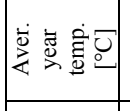 & $\stackrel{\infty}{\stackrel{\infty}{0}}$ & $\begin{array}{c} \pm \\
\stackrel{a}{a}\end{array}$ & $\underset{\substack{q \\
\infty \\
\infty}}{q}$ & $\underset{\infty}{\infty}$ & 鸷 & $\stackrel{\text { ?ִ }}{\sim}$ & مٌ & $\stackrel{\check{g}}{r}$ \\
\hline 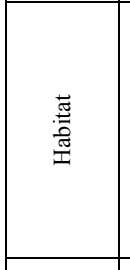 & 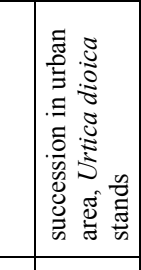 & 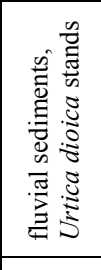 & 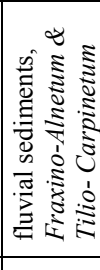 & 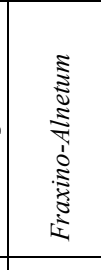 & 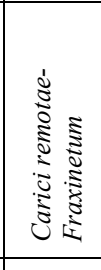 & 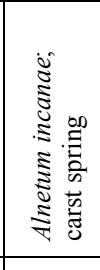 & 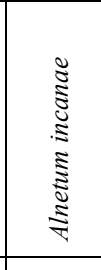 & 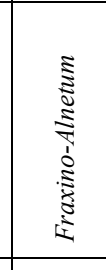 \\
\hline 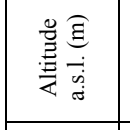 & $n$ & ฐ & తి & $\Xi$ & $\frac{t}{n}$ & ले & $\begin{array}{l}0 \\
\text { D. } \\
\end{array}$ & 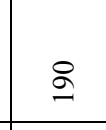 \\
\hline 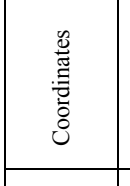 & 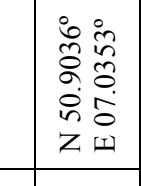 & $\begin{array}{rl}h & 0 \\
0 & 0 \\
0 & 0 \\
0 & 0 \\
n & 0 \\
z\end{array}$ & 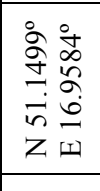 & 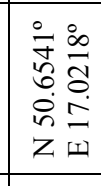 & 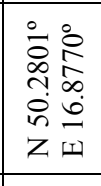 & 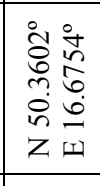 & 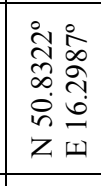 & 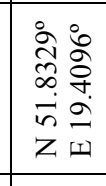 \\
\hline 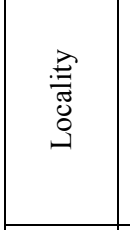 & & & & & 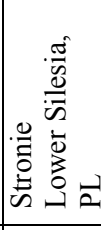 & 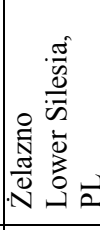 & 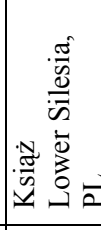 & 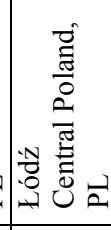 \\
\hline$\dot{z}$ & _ & $\mathrm{a}$ & $m$ & 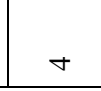 & in & 6 & r & \\
\hline
\end{tabular}

